$$
\text { sstudie }
$$





\title{
Čím je báseň velká?
}

Ivo Harák

\begin{abstract}
What makes a poem big?

Inspired by the studies of Zdeněk Kožmín, the author specifies the art qualities of the poem Hrabovské rybníky by Vilém Závada. He provides interpretation that integrates the poem into the context of Závada's creation and the evolution of Czech literature from the Modernism onwards. He analyzes the critical reception of the collection Polni kviti and explains the references that are different in the time of its inception and the periods that are free from ideological demands on literature (1960s, after November 1989). The author also reflects on how the collection keeps it ability to address readers, even though it is not considered to be one of the Závada's supreme works.
\end{abstract}

\section{KEYWORDS}

Interpretation of a poem, Czech post-war literature, Zdeněk Kožmín, Vilém Závada.

\section{KLÍčovÁ SLOVA}

Interpretace básně, česká poválečná literatura, Zdeněk Kožmín, Vilém Závada.

Opakujeme-li zde otázku, již si už před lety položil prof. Zdeněk Kožmín (KOŽMíN 1990: 5), svědčí to o trvajících rozpacích, s nimiž k uměleckému textu podrobenému nejen gramatické, ale také metrické normě přistupujeme. Zdá se nám, že nejlépe si onu velikost můžeme ukázat na konkrétním rozboru: básně literární historií zatím spíše přehlížené. Tedy básně z jednoho z méně významných tvưrčích období básníka jinak považovaného za součást literárního kánonu (české literatury 20. století). Abychom dospěli ke zjištění, „že velká báseň je darovaným objevem, ale i objeveným darem“ (KOŽMíN 1990: 11), rozhodli jsme se nejdřive poukázat na vlastnosti či okolnosti, které z našeho pohledu o kvalitách básně nerozhodují. Následně, vycházeje z Kožmínových premis 
básnické velikosti (jež hlouběji metodologicky ukotvujeme), poukazujeme na to, kterak jsou naplňovány konkrétním uměleckým textem. Při jeho analýze využíváme kritické recepce autorova díla, poznatků literárněhistorických i teoretických (zejména $\mathrm{z}$ oblasti versologie). Abychom zvýraznili důsažnost interpretačního úsilí, jež se nekončí zavřením knihy, nebráníme se ani informacím ze zdánlivě odlehlých vědních oborů (jako jsou teologie či fyzika), nakolik nám tyto pomohou osvětlit vztah mezi objektem a subjektem, básní a jejím tvůrcem (kterým není jenom pisatel, ale také její čtenář). Abychom jednotlivé momenty oné „velikosti“ shledávali právě v takových vlastnostech básnického textu, které nás budou inspirovat (či dokonce nutit) k dalšímu a hlubšímu zájmu o něj.

Než začneme s pozitivním vymezením toho, které vlastnosti pokládáme pro kvalitní a obecněji významný básnický text za signifikující, pokusíme se říci, jaké okolnosti onu velikost ani nevytvářejí ani neprovázejí. Nebot̉ jsme v předchozích obdobích vývoje národní kultury (zejména $v$ takových, $v$ nichž byla tato shora hlídána a dirigována státní mocí a funkce ideologická pokládána za závažnější funkce estetické) byli často svědky toho, že oficiálně vydáváno, vyzdvihováno a oslavováno bylo to, co dnes bereme za hodno pozoru jedině jako příklad podlehnutí diktátu politické moci, vyjití vstříc společenské objednávce a estetického ozvláštnění dobových ideologémů. Řekněme, že to, zda a kolikrát určitá sbírka vychází, jak je dobovou kritikou (či posléze literární historiografií) hodnocena, nebývá pokaždé spolehlivým měřítkem ani jednotlivým opusům v takové knížce obsaženým.

Viděno z druhé strany: Lze však také tvrdit, že umělecké kvality můžeme objevit nikoli pouze u takových starších textů, které byly do oficiálního literárního oběhu orgány hlídajícími ideovou správnost nanejvýše připuštěny - anebo u textů druhdy u nás zapovězených. Také tam, kde autoři podlehli dobovým módám a diktátům, dokonce - šířeji viděno - i tam, kde oprávněně pochybujeme o uměleckých kvalitách celku, lze najít jednotlivé práce, které obstojí při srovnání s tím nejlepším, co bylo ve vývoji novodobé české poezie vytvořeno. Docela možná, že právě tehdy, pokud takto nově námi nalezené ční nad svým okolím (jímž se stává dobový literární kontext), o to lépe si povšimneme vlastností, jež takovouto báseň činí (a snad ne jen v našich očích) velkou. Které jí umožňují přežít malost doby či pochybení autorova. Které jí vůbec umožňují přežít - což pro nás znamená: být znovu - v jiných časech a v jiném kontextu - čtena. „Mnoho básní čtenářsky žije mimo sbírku, do které je autor kdysi zařadil. Jejich smysl je $\mathrm{v}$ této izolaci poněkud jiný než v původním kontextu. 
To neznamená, že je deformovaný. Ustupují historické a situační vztahy básně, zdůrazňuje se její platnost nadčasová. Snadněji probíhá i čtenářovo mimovolné ztotožnění s lyrickým mluvčím básně“ (ČERVENKA 1990: 7).

Tím se dostáváme k pozitivnímu vymezení básnické velikosti. Zde si můžeme vypomoci esejem Zdeňka Kožmína; v němž nalezneme tři základní aspekty vytvářející velikost básně specifikovány takto: z Bremonda a Šaldy přejímá Kožmín premisu, že v básni nás uchvátí to, „co tu navazuje s námi, s řečí, se skutečností přímý vztah. [...] do velkého verše se musíme zamilovat, dát mu vlastně každý sám sebe“ (KOŽMíN 1990: 6). Víme, že Zdeněk Kožmín byl ve svých úvahách mimo jiné inspirován fenomenologií. Předchozí řádky bychom tehdy mohli chápat jako vyjádření potřeby, aby umělecké dílo vznikalo z konvergence mezi autorem vytvořeným textem a vědomím čtenářovým. A aby sám původní text byl takovým, že se bude dožadovat návratů - téhož a přece stále nového čtenáře, dalších a dalších generací čtenářů (vybavených rozličnou životní zkušeností vedle odlišného povědomí o literárním kontextu). Že tyto návraty - tím, jak je udělán - umožní, vyvolá.

Nemůžeme smlčet, nakolik si Zdeněk Kožmín vážil dědictví strukturalistického. Vždyt' u něj můžeme číst například: „Mukařovský [...] bude prokazovat velikost básně zejména tím, nakolik dokázala ,obsadit' své jednotlivé složky významy a nakolik vše dovedla do celistvé strukturovanosti. [...] Báseň je velká tím, že se nově napojuje na to, co už tu bylo, že si ze starého učiní nové, že obrozuje a přerozuje, že se nově strukturuje“ (KOŽMíN 1990: 6-7). Řekněme, že zde půjde jednak o nezbytné napětí mezi konvencionalizací a aktualizací. Tím, co je v básni konvencionalizováno, se tato vřazuje do literárního kontextu a zároveň umožňuje recipientovo před-porozumění básni (při využití zatímních čtenářských zkušeností). Nové se dožaduje aktivního úsilí při vlastní konkretizaci básně - vlastně při konkretizacích několikerých. Nebot̉ ono nové je nejen to, co daný text nově přináší, ale také to, co si do něj nově (při každém vstupu) přinášíme s sebou. Takovýmto vymezením bychom však pominuli požadavek na obsazení každé jednotlivé složky významy. Tedy na to, aby se v básni každé jak stalo skutečným co. Vypomůžeme-li si zjištěním ruského (v Estonsku žijícího) sémiotika Jurije Lotmana: „Za esteticky působivé lze v básni pokládat pouze ty prvky, které jsou sémanticky nosné“ (LOTMAN 1990: 94-97, 141-160, 214-217). Výrazným metodologickým př́ispěvkem $\mathrm{k}$ této problematice se $\mathrm{v}$ domácím prostředí staly práce M. Červenky; který vychází z přesvědčení, že: „V̌̌echny systémové stránky zvukové formy jazyka mohou být ve slovesném díle předmětem umělecké stylizace“ (ČERVENKA 2002: 10). Což znamená, že 
jsou jak významově nosné, tak také esteticky působivé, setkává-li se v nich autorova intence se čtenářovou vnímavostí.

Třetí z požadavků si Zdeněk Kožmín (veden $\mathrm{k}$ tomu zřejmě uměleckou stránkou své tvůrčí bytosti) vypůjčil z rozhovoru s Jaroslavem Seifertem. Je jím požadavek, aby báseň byla především sama sebou. Oproštěna od estetických konvencí či ideologických daností. Diktátu dobových mód. Potřeby potlesku od publika. „Musíme žít v souladu s pravdou, kterou jsme objevili srdcem, nesmíme žít ve lži, básník se nemůže vyhýbat skutečnosti, konkrétním věcem, nebot by pak byl jeho svět neskutečný nebo umělý“" (KOŽMíN 1990: 7).

Než se tedy pustíme do rozboru toho, kterou báseň a proč jsme si objevili jako velkou, dokončeme vývody, jež nás k takovému hledání a (možná) nalézání inspirovaly: „[...] velká báseň nás musí nepochybně fascinovat, musí být zralým, strukturovaným uměleckým tvarem a konečně musí být nasycena živou zkušeností, obrácena k hlubinám lidského života" (KOŽMíN 1990: 8). Text takové básně, ač je samonosný (oslovuje nás, aniž víme, kdy a kým byl napsán, do které sbírky vložen $)^{1}$, přece se dožaduje propojení s jinými texty jejího autora, abychom tak odhalili obecnější dominanty básníkova světa. Sám nám nabízí kontext, v němž chce býti viděn a čten. ${ }^{2}$ Důležité je také, kterak v básni dochází k přepodstatnění jejího látkového zdroje: „[...] každá báseň musí vždy pečlivě volit, které detaily reality, které významy uskupí do vzájemné propojenosti. [...] právě volba několika klíčových věcí, detailů, významů je z aspektu zralosti básně velice významná“ (KOŽMíN 1990: 10).

Nyní tedy dodáváme, že báseň se nám velkou nemusí zdát a stát hned na první přečtení. Tu, jíž se nyní budeme věnovat, jsme si totiž zprvu objevili pouze jako vhodný příklad daktylského verše $\mathrm{v}$ poválečné české poezii. Jsme tedy vedeni také snahou odčinit křivdu, kterou jsme autorovi učinili tím, že jsme v jeho textu zkoumali toliko, nakolik jsou zde uplatněny všechny prvky konstantně utvářející český daktyl. Abychom zjistili, že báseň, rozčleněná do dvou stř́ídavě rýmovaných čtyřveršových strof, obsáhne v každém ze svých veršů čtyři úplné (bezezbytku a bez problémů realizované) trojslabičné stopy sestupného spádu:

\section{„Hrabovské rybníky \\ Plavala Hrabová, rodná má dědina, jak slípka divoká na vodě rybníků.}

1) KOŽMíN 1990: 8: „Text vždycky odkazuje sám k sobě.“

2) KOŽMíN 1990: 11: „Velká báseň sama nabízí principy, jimiž chce být interpretována.“

3) ZÁVADA 1977: 63. 
Zdaleka svítila stř́brná hladina,

nad ní se vznášely myšlenky poutníků.

Vyschlé jsou rybníky, nezní tu racka smích,

do hlíny hnědavé rádlo se zarývá.

Jen duby staleté šumí dál na hrázích,

v duši mé chvěje se hlubina zářivá.“

Zároveň jsme také mohli studenty upozornit na zvukové i významové kvality v básni uplatněných rýmových shod, které u Viléma Závady nebývaly vždy a všude zvykem. ${ }^{4}$ Nezdálo se nám však, že by to studenty př́liš zaujalo. Závadova báseň se jim tak stala především prostorem, na němž si mohli ověřit, jak v české poezii vypadá daktyl. S trochou nadsázky tedy můžeme říci, že velikost básně nevytváří ani (a jenom) její tak zvaná formální dokonalost a řemeslná zručnost básníkova; že ji totiž nevytváří tehdy, pokud nedohlédneme, co se za nimi skrývá a skrze ně odhaluje. Přičemž je tu (navazujeme na tvrzení Lotmanovo) zapotřebí dvojího: jednak skutečné - autorem dané - sémantizace gramatického v básni, jednak čtenářovy ochoty a schopnosti ze samotného textu odhalit způsob i motivaci jeho kódování. Tedy v našem případě například toho jak, proč a k čemu básník daktylského spádu využívá, co nám jím - a také svými rýmy - sděluje.

Při takovémto zkoumání si jistěže vystačíme se samotnou Závadovou básní; nicméně přesto neuškodí, pokud nahlédneme do sbírky, v níž byla původně obsažena. Zvolený metrický systém (a nikoli např. jen její postavení v čele IV. oddílu) ji totiž v Polním kvítí zviditelňuje. Pro sbírku, vycházející poprvé v roce $1955,{ }^{5}$ je totiž charakteristický spíše dominující jambotrochejský spád, ${ }^{6}$ doplněný méně častým spádem daktylotrochejským ${ }^{7}$ a ve verších reprodukujících ještě dikci schematické budovatelské poezie konečně vskutku poněkud stereotypně znějícím trochejem. Pouze jediná báseň Polního kvítí byla ovšem napsána daktylem.

Kniha někdejšího představitele meziválečné avantgardy, akcentujícího vždy - s ohledem na autorův původ a životní zkušenosti - sociální aspekty lidského bytí (MÁLKOVÁ 2003), prošla velmi zajímavými proměnami hodnocení. Záhy

4) MÁLKOVÁ 2003: 161: „Rým, mající v prvních sbírkách roli ozdobnou a zjevující se pouze občas, se stává trvalou součástí Závadovy poetiky a naplňuje všechny své funkce, včetně pro Závadu podstatnou funkci významovou."

5) V roce 1956 oceněná Státní cenou Klementa Gottwalda.

6) Viz MÁLKOVÁ 2003: 149 a ČERVENKA 2001: 241.

7) Podle našeho zkoumání nepřevládá; jak se domnívá J. Petrmichl - viz PETRMICHL 1963: 122. 
po sepsání byla třikráte vydána; počtvrté pak ještě v časech normalizačních. Dobová kritická recepce hodnotí kladně už předchozí Závadovo přimknutí se $\mathrm{k}$ proudu socialistickorealistického, optimisticky laděného básnění v Městu světla (1950). Jím - a ještě zřetelněji Polním kvítím - prý Vilém Závada potvrzuje, že se stal básníkem českého národního charakteru. ${ }^{8}$ Navíc se jedná o práci kvalitativně stojící nad knihou předchozí (podle J. Petrmichla jde o: „definitivní vymanění ze schematismu, přejímajícího mechanicky politicko-ekonomické pojmosloví /PETRMICHL 1963: 117/), jíž bylo na straně jedné dovršeno Závadovo úsilí o obecnou srozumitelnost textů (takto přijatelných též pro širší, neškolené publikum ${ }^{9}$ ), na straně druhé vrcholí snaha o formální dokonalost verše, v němž „se myšlenka stává formou a kde forma mysli“"(PETRMICHL 1963: 111).

Přestože přechod od budovatelské tematiky k prostým motivưm krajového i osobního (se zvýšenou frekvencí problematiky milostné) rázu ukazuje nejen $\mathrm{k}$ jednomu $\mathrm{z}$ kořenů Závadova básnění1 ${ }^{10}$, ale naznačuje také hlubší proměnu naší poválečné poezie (o niž usiluje skupina mladších autorů sdružená kolem časopisu Květen /PETRMICHL 1963: 125/), přestože není charakter sbírky určován jenom dobovými okolnostmi kulturně-politickými, setkává se Polní kvítí se skepsí a kritikou tehdy, může-li ten, kdo na ně pohlíží, využít časového odstupu stejně jako liberálnějšího kulturního klimatu. Obojí platí nejen pro polistopadové Dějiny české literatury („Extrémní podoby jeho poúnorová poetika prostoty dosáhla ve sbírce Polní kvítí [...]. Z vlasteneckého a budovatelského sebeuspokojení sbírky vybočuje pouze oddíl milostné poezie“/JANOUŠEK 2007: 191/), ale také už pro hodnocení Brabcovo ( $\mathrm{z}$ roku 1963! - tedy z roku vydání monografie Petrmichlovy; k jejímž vývodům se staví značně skepticky) předchozí Závadovy tvorby - nahlížené optikou čerstvě vydaného a kvalitativně výše stojícího Jednoho života. Polní kvití podle Jiřího Brabce „vzbudilo tak nadšený souhlas i ohlas. Tak čekali ti, kdo věřili a věří, že se v poslední knize setkali s ,básníkem národního charakteru', i ti, kteří hned za touto slavobránou spatřili hlubokou propast. Nebot' dovršila se tu jedna tendence díla, jež zároveň značně zúžila autorův

8) Závadovi se tím jednak přiznává schopnost vytvářet typus toho, co bychom (řečeno dobovou terminologií) nazvali socialistickým vlastenectvím (v rámci synchronního kontextu to značí řazení po bok Nezvalových Chrp a měst, poezie Stehlíkovy, Kainarovy či Nohovy - vesměs jde tedy o „návrat k jistotám domova a hodnotám národního bytí, třebaže často značně ideologizovaný“ - JANOUŠEK 2007: 205), jednak je takto Závada ukotven v ideologizující básnické linii, již můžeme shrnout pod pojem ideálního realismu a která je - podle dobové literární kritiky a posléze historiografie - reprezentována Janem Nerudou či vlastenecky-venkovskou linií poezie Sládkovy, a patří sem také sociálně a národnostně burcující poezie Závadovi blízkého Petra Bezruče (PETRMICHL 1963: 116, 125; NEJEDLÁ 1977: 100).

9) Viz ZÁVADA 1950: 945.

10) Viz Básnická cesta Jana Nerudy (ZÁVADA 1954: 3). 
přístup ke skutečnosti, jeho poetiku; stabilizace Závadových ,prostých motivů směřovala $\mathrm{k}$ moralistní pointě, $\mathrm{k}$ zaokrouhlení tématu, $\mathrm{k}$ harmonizaci, kterou vytváří spíše dobrý úmysl než básnické poznání“ (BRABEC 1963: 13).

$S$ úctou k básníkovi i jeho hodnotiteli řečeno: Polní kvítí rozhodně nepatří k vrcholným dílům rodáka z Ostravy - Hrabové (1905). Znovuzpřítomnění si v časech, které na literaturu kladou toliko měřítka estetická, zaslouží už jen jednotlivá čísla. Domníváme se však, že nepůjde pouze o ve třetím oddílu sbírky obsaženou poezii milostnou (JANOUŠEK 2007: 191), ale také o báseň, která (se) vešla do reprezentativní antologie české poezie XX. století A co básník (vydané na konci 60. let), stejně jako do „přestavbového“ souboru Závadovy poezie Ve skořápce země (uspořádaného a komentovaného v roce 1987 Janem Adamem). Přestože se jejím inspiračním a látkovým zdrojem stala jiná láska, totiž láska k básníkovu rodišti - stejně jako osobně-existenciální uchopení jeho proměn v proměnách času i osudu.

Docela možná, že ty, kdož takto rozhodovali o její kanonizaci, zaujalo na ní totéž, co mnohem později podnítilo také nás, abychom jí věnovali pozornost. Totiž to, že a nakolik se formální dokonalost (dovedena snad až na samu mez) stává funkční a sdělující. Aby se právě takto (i když ne jen) uzavřela jedna z fází básníkova vývoje. Od verše maximálně (metricky, rytmicky - včetně shody rýmové -, sémanticky, syntakticky) uzavřeného vede cesta už jen $\mathrm{k}$ jeho pozvolnému rozvolňování (Jeden život; 1962) a nakonec až k značně prozaizovanému verši volnému ( $\mathrm{Na} \mathrm{prahu;} \mathrm{1970).}$

Sama báseň jako by se v několikerém směru a rozličným způsobem ukázala výslednicí předchozího básníkova vývoje (i toho, jak do tohoto procesu vstupuje diachronní literární kontext); jejž zároveň shrnuje a uzavírá - a také otevírá věcem příším (tím, jak překonává dobově podmíněná omezení). Vilém Závada byl často nazýván básníkem dichotomním či dialektickým. Druhý z termínů, pokud jej zbavíme nepatřičného ideologického nánosu, zdá se nám nanejvýše přiléhavým. Mnohým zpơsobem a v mnoha rovinách dochází totiž u našeho básníka $\mathrm{k}$ boji a jednotě protikladü. ${ }^{11}$

Volbou metricky a rytmicky nejvýraznější veršové formy tudíž nejen vrcholí osobní autorovo úsilí o tvarovou sevřenost, ale zároveň je (i tím, že jde o metrum ve sbírce ojediněle užité) signalizována také otevřenost i jinému kontextu, než jsou prosté motivy ideálního realismu. „Závada svým způsobem v současné historii naší poezie dovršuje tvůrčí podněty, které přinesl českému verši symbolismus

11) PETRMICHL 1963: 114: „Setkáváme se zde znovu s oním typicky závadovským napětím: vnějšek - nitro, povrch podstata, zdání - pravda.“ 
a které sám básník přijal v určité podobě od Petra Bezruče“ (PETRMICHL 1963: 124). K Bezručovi se Závada hlásí také látkovým zdrojem svého psaní - který má společný s Bezručovou básní Rybníky za Paskovem (jemně epizovaná lovecká momentka tvoří druhou, mladší, osobně introspektivní vrstvu Slezských písnî): s týmž metrickým spádem a týmiž přírodními reáliemi. (V obou básních tematizovaná vodní díla se kdysi nalézala mezi dvěma ne př́liš vzdálenými součástmi dnešní Ostravy, Hrabovou a Paskovem.) Kromě látkového zdroje či metrického spádu toho obě básně mají společného ještě více: například nostalgii čerpající existenciální vyznění z protikladu mezi někdy a nyní, mezi tím, co bylo (ve vnějším fyzickém světě) - a co jest (myšlenkou, vzpomínkou - zasuto hluboko v paměti, v duši).

Neměli bychom však zapomenout ani na první část Petrmichlova tvrzení; ani na to, co o Hrabovských rybnících říká Iva Málková: „Právě pravidelný počet slabik v sledovaném souboru básní se stává pro Závadu tohoto období určující. Báseň Hrabovské rybníky nejenže má v každém verši pravidelně dvanáct slabik, ale pravidelná césura po šesté slabice ukazuje k invariantní formě alexandrinu, byt’ jambická tendence je nahrazena daktylským rytmem“ (MÁLKOVÁ 2003: 161). Oba totiž signalizují, že musíme - při hledání zdrojů rytmického bohatství Závadovy básně - jít přes Bezruče až za Bezruče. Tedy k počátkům české moderny. Pamatujeme si, čím nás kdysi okouzlila melodika Hlaváčkovy básně Hrál kdosi na hoboj. Totiž možností realizovat sám text (při jeho recitaci) jak v jambu - tak také ve frázování daktylském.

Hrabovské rybníky jsou nicméně zřetelně učleněny do čtyř úplných daktylských stop v každém $\mathrm{z}$ jejich veršů. Jedním ze signálů oslabeného rytmu je však onen Ivou Málkovou zmíněný alexandrin (mimochodem: právě tímto veršem je psána báseň Hlaváčkova). Prostředkem (známým české poezii už od časů Máchových) sloužícím k oslabení rytmického důrazu a posílení eufonických kvalit básnického textu je rozložení hláskových délek (v textu jinak sylabotónickém): v Závadově básni naprosto převažují hláskové délky na nepřízvučných slabikách. A pokud se objeví na slabice přízvučné, jedná se o záměrné a sémanticky podložené zvýraznění rytmu - provázené například aliterací: „svítila stříbrná“ - zdưrazňující v daném případě intenzitu vyzařování (o níž ještě dále pohovoříme).

Dialekticky řečeno: to, co je nanejvýše normované a uzavřené, otevírá se a zbavuje svých hran. Mez, jíž bylo jako nejzazšího místa dosaženo, stává se východiskem pro další cestu. Platí to nejen pro zvolené metrum, ale také pro v básni obsažené rýmy. Viděny z tohoto úhlu jsou Hrabovské rybníky jednou z těch Závadových básní, v nichž se rýmové shody vskutku proměnily ve vertikální 
zvukovou metaforu. V esteticky působivé nebot sémanticky zatížené - jejichž dynamika je založena na jejich dichotomní povaze. Totiž na spájení shodného v neshodném a naopak.

To, co uzavírá verš, jej zároveň otevírá zvukové i významové konfrontaci s obdobnou metrickou jednotkou. Částečná zvuková shoda (a stejně i neshoda) rýmujících se slovních celků nás vyzývá $\mathrm{k}$ bližšímu ohledávání souvztažností (i odlišností) významových: fyzické stojí tu vedle duchovního, pronikání pod povrch vedle vyzařování $\mathrm{z}$ hlubiny, minulé $\mathrm{v}$ sousedství přítomného, pohyb horizontální proti vertikále (která se o něj opírá). To, co se nám na první pohled může zdát jevovým, se při hlubším zkoumání ukazuje věcí podstatnou. Za příklad vezměme rým racka smích - na hrázích. Jako v jediném se v něm rýmují uzavřené slabiky. Nejenže se zde takto vymezuje protiklad mezi tím, co už je nenávratně ztraceno, a tím, co pořád ještě (oboje ve vnějším hmotném světě) přesto trvá, ale právě takto (i když ne jen takto) ohlašuje se v básni ono nyní jestliže někdy zůstává svázáno rýmy s otevřenými slabikami.

Pravdou však je také, že daný protiklad je ještě zřetelněji (v rámci sémantizace gramatického) naznačen dichotomií mezi minulým a přítomným slovesným časem, totiž vưbec mezi první a druhou slokou básně. Vedeni k tomu Kožmínovým (a Seifertovým) požadavkem souladu s pravdou dovolujeme si, přestože to pro interpretaci básně není nezbytně nutné, poněkud hlouběji prozkoumat pozadí, na němž a z nějž je báseň vytvořena. Závadovo rodiště (Hrabová) oplývalo jak bohatstvím rybníků rozložených na lukách mezi Hrabovou a Paskovem, tak i procesími poutníků směřujících $\mathrm{k}$ místnímu dřevěnému (nedávno ničivým požárem zdevastovanému, nyní již opravenému) katolickému kostelu. Náš básník oboje důvěrně poznal ve svém dětství, kdy dokonce v kostele ministroval. K postupné devastaci a likvidaci rybníků (industrializaci venkovské krajiny) dochází od časů první světové války - v níž Závada ztrácí otce, i dětskou bezprostřednost víry. Doba sepsání básně (polovina let padesátých) je časem opětovného sblížení Viléma Závady s vírou: rodina jeho manželky patří k evangelíkům, jej samotného lze nejspíše charakterizovat jako církevně neukotveného plachého věřícího křestaanského vyznání. Závada také začíná pracovat (spolu se Stanislavem Segertem) na překladech starozákonních žalmů, které vycházejí v roce 1958 jako Žalozpěvy (ve svazku Pět svátečních svitků).

Nezbývá, než abychom nyní doložili, že předchozí odbočka mimo stránky literatury je smysluplnou: Pokud bychom zůstali v rovině čisté faktografie, mohli bychom dodat, že období poloviny let padesátých je dobou častějších 
návratů Viléma Závady na rodné Ostravsko, což se promítlo do celé řady motivů v Polním kvítí obsažených básní. Toto tvrzení však přesto zůstává příliš vnějškovým, nedotýkajíc se v nejmenším vnitřní dynamiky námi interpretovaného textu. Tedy jednoho $\mathrm{z}$ atributů - řečeno $\mathrm{s}$ Kožmínem - skutečné velikosti básně. Z Kožmína si však pamatujeme také požadavek na pečlivou volbu klíčových věcí, detailů, významů. Tedy toho, co - a jak propojeno i ztvárněno - v básni z původního látkového a inspiračního zdroje nalezneme. Vlastně bychom mohli také na tyto prvky vztáhnout tvrzení o boji a jednotě protikladů v Závadově básni; připadá nám, jako by jednotlivé složky její výstavby byly jakýmisi podivnými magnety, které obdobné entity zároveň odpuzují i přitahují.

Uved’me si několikerý př́iklad: $\mathrm{k}$ významové koncentraci a její dynamice přispívá i to, že je skutečný život patrný skrze dění se textu: v jeho první sloce jsou lidé přítomni pouze výsledkem své činnosti fyzické (vesnice Hrabová) či duševní (myšlenky poutníků), živá příroda pak jenom jako druhý z členů básnického přirovnání. Skryté za textem a v textu však tento oživuje také tam, kde na první pohled spatřujeme jen výsledek fyzikálního procesu zrcadlení a vyzařování. To, co není, je o to více, nebot', naplňujíc přítomné, proměňuje toto ve výmluvný (přesný i mnohoznačný) symbol. ${ }^{12} \mathrm{~V}$ něm se vertikální pohyb (svit hladiny; vznášení myšlenek) odráží od horizontálního (Hrabová domněle plující po hladině rybníků) za postupného rozevírání prostoru šířji do kraje i vzhưru, za vzájemného prostupování duchovního s fyzickým (i s otázkou, co zaváží více: intenzivně pocitovaný svit stříbrné hladiny, nebo jen tušené myšlenky poutníků nad ním?), při aktivizaci kognitivních aspektů interpretace: nebrání nám občas oslnění krásou v cestě za zrcadlo?

V první sloce Závadovy básně nás však také zaujme umně vytvořený - a vzápětí přemostěný - morfologický i sémantický šev uprostřed strofy. Syntaktická pauza mezi druhým a třetím veršem je silnější než mezi veršem prvním a druhým, třetím a čtvrtým. Zdá se, že obě souvětí jsou odlišena také významově. ${ }^{13}$ Vskutku? - Nejsou myšlenky poutníků přitahovány i neseny tím, čím stříbrná hladina svítí také: totiž Hrabovou s jejím kostelem (vizuálně tvořícím hlavu oné divoké vodní slípky)? Není právě tato souvztažnost naznačena ve sloce přítomnou rýmovou shodou?

A ve druhé sloce (se vším, co je nenávratně ztraceno, i s tím, co doposud zbývá a trvá) nalezneme zase zřetelný předěl mezi druhým a třetím veršem: Předěl,

12) PETRMICHL 1963: 125: „Závada svou ,symbolickou’ metodou působí velmi pronikavě na českou poezii padesátých let."

13) V prvním př́ípadě jde o souvětí podřadné, ve druhém se jedná o souvětí souřadné. 
který vymezuje výše naznačený protiklad (protiklad obsažený tentokrát v obou rýmových shodách). Než k němu budeme hledat klíč, povšimněme si , jak je nyní zpodobena někdejší rybniční krajina. Je zcela mrtvou a neužitečnou? - Vyschlé jsou rybníky, nezni tu racka smích. Nepřítomnost nejen někdejších přírodnin, ale také barev a zvuků. Nicméně: do hlíny hnědavé rádlo se zarývá. S onou přerozující a oplozující silou (již můžeme přiřadit k mužskému aspektu bytí), jež - obsažena v mnohých číslech Polního kvítí - svého snad nejparadoxnějšího vyjádření nalezla v básni Kopáči: „Zem obnaží a bagry znásilní / a v lůno základy jí zapustí. [...] Kopáč i mrtvou zemi oplodní“ (ZÁVADA 1977: 22). Na místě stříbrné rybniční hladiny leží nyní hnědá, čerstvě přeoraná hlína. Zatím jen čistě fyzický pohyb už proniká pod povrch: jevového, země. Co ničí - připravuje půdu životu? „[...] jako by mělo být opět v zemi nalezeno opěrné místo dalšího pohybu“ (KOŽMíN 1986: 104).

A přece zůstává také na povrchu něco, o co se ještě můžeme opřít, (ne zcela) němí svědkové kótující původní prostory: Jen duby staleté šumí dál na hrázích. Do této chvíle jsme se pohybovali jakoby vně myslícího a vypovídajícího subjektu, zatím zdánlivě nepřítomného mluvčího básně. Jsou ony staleté duby skutečně tak pevné, aby s nimi a z nich vyrostla její dynamika? Anebo spíše jenom vymezují prostor vně: jako území proměny (zániku stejně jako možnosti vzniku nového) i trvání? - vymezují a otevírají: vnitřním prostorám mluvčího básně. Trvající se dovolává trvalého.

Také proto nechceme absolutizovat významový předěl mezi dvěma posledními verši. Přestože, viděno pohledem jazykovědce, bude pauza mezi nimi zvýrazněna, pokud budeme syntaktické celky v nich obsažené číst jako dvě juxtaponované věty. Nicméně - básník tomu zřejmě chtěl jinak: šumění větví (či listí) dubů je přece provázeno týmž chvěním, o jakém čteme na samém konci básně. Zatímco však pořád ještě zarostlým rybničním hrázím chybí hladina, to, co zůstávalo dříve nespatřeno pod ní, trvá nyní (schoulené a obnažené, chvějící se) v samém středu bytosti vzpomínajícího, reflektujícího a vypovídajícího subjektu. Bořivý a tvořivý pohyb zúrodňující zemi je provázen vnějším i vnitřním chvěním.

Jaká je však jeho povaha? A značí samo chvění pouze obavy, nejistotu, nepevnost? Možná bychom se, zejména s ohledem na ono chvění $v$ nitru, mohli pro poučení obrátit $\mathrm{k}$ tradici, $\mathrm{s}$ níž $\mathrm{v}$ době vzniku básně přichází do kontaktu také Vilém Závada; tedy ke tradici (ohrožovaného) evangelického křestanství - jež nám ukazuje, k jakým jistotám máme se obracet a jaké můžeme ve svém nitru nalézt („Navrat’ se, odkuds vyšel, do domu srdce svého..." /KOMENSKÝ 1984: 135/) - a především k tradici židovské, nebot̉ chasidská hermeneutika vykládá 
modlitbu každoročně pronášenou na Svátek obnovení Chrámu takto: „Modlitba pronášená o svátku Roš Hošana obsahuje slova ,Dnes se svět chvěje‘. Tato fráze také znamená ,Dnes se svět narodí“ “ (JACOBSON 2008: 10). Chvění je tudíž znamením bolesti i naděje. Ne (jen a především) v nitru země, ale v lidském nitru proměňuje se staré a rodí nové. „To, co je zasuto, chce být znovu odkryto a žito" (KOŽMíN 1986: 104). Snad nás Zdeněk Kožmín mimo jiné vyzývá k novému čtení Závadovy básně; k němuž se odrážíme ze samého jejího konce. Abychom mohli říci, že to, co se zdánlivě definitivně uzavírá, je teprve plně otevřeno dalším možnostem.

Což nejsme prostoupeni, což v nás nerezonuje minulost i přítomnost světa vně očí a mysli? - jako vzpomínka, představa, obraz, slovo. Což se minulost nepřipomíná nejen duby na hrázích, leč také dvojitou aliterací (spojující liché verše první a sudé verše druhé sloky)? Což nejsou snad až na samém okraji čtenářovy pozornosti zvukově i významově konfrontovány pasáže: svítila stříbrná hladina - chvěje se hlubina zářivá? ${ }^{14}$ Aby nakonec to, co se zprvu zdálo intenzivnějším (znepřístupňujícím tak pohledu prostory pod), muselo ustoupit a vyblednout před chvěním zárívé hlubiny. (V níž můžeme hledat jak tajemství skryté pod hladinou / z povídek bratří Čapků/ - tak také Komenského Hlubinu bezpečnosti.)

Toto vyzařování, vertikální pohyb směřující vzhůru, je nejen (jistěže ženskou ${ }^{15}$ odpovědí plodivému pohybu do nitra hlíny, ale také individuálním (vzpomeňme na charakteristiku Závadova křest̉anství) a o to silnějším přerozením poutnických myšlenek (ty se vznášely nad hladinou, tady jde už o hlubinu). Rozšiřuje a (snad to můžeme říci) také svým způsobem nově interpretuje škálu smyslových vjemů a symbolů, které bychom nalezli nejen v námi zkoumané básni. „Duše a srdce jsou v Závadových ,vlastních podobiznách“ velmi často spjaty s obrazem čistých vod a zářivých hlubin. [...] Už několik uvedených obrazů ukazuje, jak duše a srdce chtějí být také záăí, žhnutím, leskem. Obraz zářícího srdce, planoucí duše se u Závady rozrůstá do bohaté světelné synonymiky“ (KOŽMÍN 1986: 103). Individualizací a zniterněním oněch symbolů a vjemů předznamenávají Hrabovské rybníky (prozodií velmi odlišnou) dikci vrcholné Závadovy (životně bilanční) sbírky $\mathrm{Na}$ prahu. „Závadova rozvinutá symbolika světla plní v celkové sémantice této poezie velmi důležitou funkci. [...] Světlo proniká tmou ${ }^{16}$, je smyslem, který prohrabuje nicotu jako ohniště a naplňuje ji žárem“ (KOŽMíN 1986: 107).

14) Ve shodě s M. Červenkou tu můžeme hovořit o zvukové iradiaci (ČERVENKA 2002 : 44).

15) Viz JACOBSON 2008: 204.

16) Předpokládáme, že jde o Kožmínovu narážku na biblickou a křest̉anskou tradici. 
Pisatel práce nemůže smlčet údiv, který u svých blízkých vyvolal konstatováním, jak podstatnou pro něj byla naděje, již mu báseň nabízí: Naděje, že nic bezezbytku nezanikne tehdy, stane-li se naším majetkem: ne movitým či nemovitým, ale pokladem skrytým. „Báseň se podle mého názoru stává pro nás naplno básní teprve tehdy, když pro nás něco podstatného znamená, když se včleňuje do našich reflexí o světě, když vstupuje do naší vlastní řeči, když je pro nás jak objevem nového, tak i potvrzením a osvětlením našich zkušeností. Báseň je naplno básní, je-li i inspirací našeho niterného života“" (KOŽMíN 1990: 13).

Než začneme podobný přistup pokládat za nevědecký, zkusme se nad ním zamyslet - a zkusme jej vidět $\mathrm{v}$ poněkud širším kontextu. Jako se dříve, a ne vždy ku svému prospěchu, literární věda inspirovala u disciplín, přírodovědných (například v době pozitivismu), docela možná, že tady a takto předjala naopak jejich novější směřování. Totiž onu podmínku živé spoluúčasti, jíž se pro fyzikální bádání dožaduje John Wheeler: „Svět nikdy nebude stejný. Abychom mohli popsat, $\mathrm{k}$ čemu došlo, musíme změnit naši starou pozici ,pozorovatele na pozici ,účastníka'. V nějakém podivném smyslu je svět spojený s naší účastí."17

S takovouto účastí na Závadově básni můžeme tedy závěrem konstatovat, že je její velikost utvářena synergií motivického a rytmického učlenění textu, tedy tím, co bychom - slovy Mukařovského - mohli nazvat zde přítomným sémantickým gestem: a to s plným vědomím faktu, že se tak děje tehdy, nesou-li její složky takzvaně formální také svůj význam. Právě to umožňuje recipientovi povznést se nad okolnosti jejího vzniku (tedy i nad to, v jaké sbírce a $z$ jakého /autorova tvưrčího/ období vychází) a hledat skrze její smysl (a skrze svoji aktivní účast při jeho spoluvytváření) i smysl své př́itomnosti v ní. Vždy nový a jiný, vždy nově a jinak: jako se proměňuje také jeho zkušenost se slovy, s literaturou i předmětným světem.

\section{PRAMENY}

BEZRUČ, Petr

2016 Slezské písně (Praha: ÚČL AV ČR - Akropolis)

KOMENSKÝ, Jan Amos

1984 Labyrint světa a ráj srdce (Praha: Odeon)

17) Citováno podle: JACOBSON 2008: 324. 
Ivo Harák

Čím je báseň velká?

ZÁVADA, Vilém

1977 Polní kvítí (Praha: Čs. spisovatel)

\section{LITERATURA}

BRABEC, Jiří

1963 „Dolování poezie“, Kulturní tvorba, roč. 1, č. 3, s. 13

BROUSEK, Antonín

1999 „Básník českého charakteru?“, in Podřezávání větve (Praha: TORST), s. 307-325

ČERVENKA, Miroslav

2001 Dějiny českého volného verše (Brno: Host)

2003 Fikční světy lyriky (Praha: Paseka)

ČERVENKA, Miroslav a kol.

2002 Pohledy zblízka: zvuk, význam, obraz (Praha: TORST)

1990 Slovník básnických knih (Praha: Československý spisovatel)

FIKAR, Ladislav

1956 „O Vilému Závadovi“, Nový život, 1956, č. 1, s. 79-81

HORŇÁK, Kamil

1956 „Pohyb v kruhu a ve spirále“, Plamen, 1956, roč. 5, č. 7, s. 111-113

HRABÁK, Josef

1978 Úvod do teorie verše (Praha: SPN)

HRÁCH, Karel

1956 „Známá a nová tvář Viléma Závady“, Květen, 1956, roč. 1, č. 5, s. 142-143

JACOBSON, Simon

2008 Smysluplný život. Rebe Menachem Mendel Schneerson a jeho moudrost (Praha: Chabad Lubavitch)

JANOUŠEK, Pavel a kol.

2007 Dějiny české literatury 1945-1989 (II. 1948-1958) (Praha: Academia)

JANU゚, Jaroslav

1955 „Básník a charakter“, Nový život, 1955, č. 4, s. 366-369

JUNGMANN, Milan

1955 „Dílo mužného srdce“, Literární noviny, 1955, roč. 4, č. 21, s. 5 
KOŽMíN, Zdeněk

1986 Interpretace básní (Praha: SPN)

1990 Umění básně (Brno: K22a)

LOTMAN, Jurij Michajlovič

1990 Štruktúra umeleckého textu (Bratislava: Tatran)

MÁLKOVÁ, Iva

2003 Hledání Viléma Závady (tvưrčí cesty zvláště po roce 1945) (Olomouc: Votobia)

NEJEDLÁ, Jaromíra

1977 „Kde roste Polní kvítí, in Závada, Vilém: Polní kvití (Praha: Československý spisovatel), s. 97-103

OPELÍK, Jiř́

1956 „Závadovo Polní kvití", Host do domu, 1956, roč. 3, č. 2, s. 69-71

PETRMICHL, Jan

1963 Vilém Závada. Básník českého charakteru (Praha: Československý spisovatel)

PETŘíČEK, Miroslav

1957 Glosy k současné české poezii (Praha: Československý spisovatel)

SIVEK, Alois

1956 „Nad knihou veršů V. Závady“, Nová svoboda, 3. 1. 1956, s. 4

1957 Polní kvítí. Metodický text (Ostrava: Krajská lidová knihovna)

SKÁLA, Ivan

1956 „Kniha boje o nový český charakter“, Literární noviny, 1956, roč. 5, č. 1, s. 4

ŠAJTAR, Drahomír

1956 „Starý a nový Závada“, Červený květ, 1956, roč. 1, č. 1, s. 14-18

ZÁVADA, Vilém

1954 „Básnická cesta Jana Nerudy“, Literární noviny, roč. 3, č. 28, 10. 7. 1954, s. 3

1950 „Pišme pro dělníky“, Nový život, Ostrava 1950, s. 945

PaedDr. Ivo Harák, Ph.D., harak@post.cz, Katedra bohemisticky pedagogické fakulty Univerzity Jana Evangelisty Purkynè, Ústí nad Labem, Česká republika / Department of Czech Studies, The Faculty of Education, Univerrsity of Jan Evangelista Purkynè, Ústí nad Labem, Czech Republic 